\section{DR. TURNER.}

The Professor of Chemistry in University College, breathed his last on Sunday, the 12th of February, 1837. The suddenness of this occurrence shed great gloom on the institution. On Monday morning the students were made acquainted with the painful event by the closure of the class-rooms for the day, and they were quickly excited by a desire to express their respect for his character by following his remains to the grave; and at a meeting on Tuesday a resolution was passed, that a request should be forwarded to the family of the deceased for permission to attend in the funeral train. This was acceded, and a committee accordingly made arrangements for the procession. On Friday night the body was borne from the house at Hampstead to the college, and at twelve o'clock on Saturday the corpse was conveyed to the new cemetry at Kensall Green. Upwards of three hundred students followed the hearse, succeeded by the professors and friends in mourning-coaches, and a long train of private carriages. The Rev. T. Dale, late Professor of Rhetoric in University College, and now Professor of Rhetoric in King's College, officiated at the interment.

Dr. Turner had for many sessions past been declining, and his thin and emaciated appearance always excited much attention in the new students; but his mind never indicated any sympathy with its tenement. He did not suffer more than ordinarily this session. He continued lecturing on till the 18th of January, when an attaok of influenza interrupted his ordinary avocations, but getting better he lectured again on the following Wednesday, though with much difficulty, and for the last time; the catarrhal symptoms were renewed, pneumonia came on, his system could not bear up against the attack, and on Sunday, the 13th of February, he died, in the 40th year of his age.

In Dr. Turner science has lost one of her most distinguished votaries. He may, indeed, be said to have sacrificed his life upon her shrine. No man more ardently loved the object of his pursuits, and in the recent splendid discoveries of chemistry he felt the deepest interest. As a teacher he evinced clearness of intellect, and entire knowledge of his subject; he was precise in expression, and took a kindly interest in the progress of his pupils ; and, as a consequence, he was admired and beloved by every meinber of his class. He was extensively known as an author, by his " Elements of Chemistry," a work which affords abundant evidence of diligent research, and an intimate acquaintance with the science.
MEDICAL AID TO THE SICK POOR IN THE UNIONS.

PETITIONS TO THE HOUSE OF CONMOSS.

"To the Right Honourable and Honoura", the Knights, Citizens, and Burgesses ir Parliament assembled,- - the Petition: the President und Council of the BerTy- Medical Association:

"Humbly sheweth,-That your Petition: having taken into their most serious cio: sideration the system at present adopted the Poor Law Commissioners for affordin. medical relief to the sick poor, do highl disapprove of the same as unjust to th poorer classes, injurious to the communit at large, and derogatory to the charant. and respectability of the medical professin:

"Your Petitioners therefore humbly, bu" earnestly, pray that your Honourably House will be pleased to make such in quiries into the alleged evils, and to entar such measures, as to your Honourable Hovi. may appear necessary: And your Peil. tioners will ever pray.

“ G. Webster, Pres. j “ J. M. Beane John Castle $\quad$ R. Davidson Wm. Eales Jos. Howell M. W. Wagstaff Thomas Porter Patrick Mollison Charles Brady Edwd. Doubleday H. Whitmore John Taylor $\quad$ R. Menzies W. R. Harrison $\quad$ H. Sidden N. Delph Geo. Parsons

J. Syer Bristowe

Jas. Couthred

John Clarke R. L. Hooper E, Crisp Edw. Evans S. I. Bayfield George Hull."

Minute of Council, Feb, 9, 1837 ; - "R solved,-That Thomas Wakley, Esq., MI.P be requested to present the Petition agreed? upon, to the House of Commons, and the each Member of Council do obtain the sup. port of any Member of Parliament he miar be enabled to procure for such Petition."

William Eajes, Hon. Spl.

"To the Right Honourable and Honownt. the Knights, Citizens, and Burgessis? Great Britain and Ireland, in Parliamen assembled,--the Petition of Gentlementith are Members of the Mentcal SocifT. LONDON :

"Humbly sheweth,-That your Pri: tioners have seen, with much regret, tr $^{\text {th }}$ adoption of a system, by the $\mathrm{P}_{00 \mathrm{r}} \mathrm{L}^{\mathrm{T}}$ Commissioners, of appointing medical offite: to parishes, and the unions of parishes, tablished under the Poor Law Amendure? Act, which they cannot but consider t: inconsistent with humaaity, destructic the health of the poor, and degrading tin: medical profession:

"Your Petitioners, therefore, hun.t pray that your Honourable Huas on 
use an inquiry to be instituted into the time, and, too often, the hours when he is eans that have been provided for the medi- himself sick, - who are they that stand beI treatment of the sick poor in the paro- tween him and a condition of comfort and jial unions, or adopt such other proceed- honour in society? Talk of an inquiry into igs as to the judgment of the House may grievances! of mild language! of not comsem best fitting: And, as in duty bound, plaining! As reasonably might the Israel-ill ever pray, \&c.

H. Clutterbuck

J. Whiting

'T. E. Bryant

Geo. Pilcher

I. Neryon

D. R. Stable ites of yore, when in Egyptian bondage, have been told not to complain when ordered to make bricks without straw. Let us, then, heart and hand, come forward, address the legislature, and demand redress of, not inquiry into, well known grierances. Admit no wily folks into our camp to swell the train of petitioners, which is large enough already. They will only be spies into our councils, or else always in a minority on our questions of reform, and of what use is a minority where all are wished to be unanimons? Drs. Johnson and Thomson have told us, painly enough, that a minority there would be. I remain, Sir, your obedient servant,

A General Practitioner. Hedrcal Associatiox, I observe that much liscussion occurred respecting the relation in which the two colleges stand with regard to the great body of practitioners in this country, and also as to the support which the latter were likely to obtain from the pures and dubs. I hope that the medical men of Great Britain will not be such simple. tons as to ally themselves in the new association with either one or the other of these gentry. Individuals, it is true, may be found amongst them who are sufficiently enlightened or discreet to aid our efforts for reform, but from the mass of them we have nothing to expect that is not inimical to our interests. If $I$ err in the following statement, I shall easily be set right, but although I speak from memory, I believe that it is not incorrect :-

Some years ago, when the Apothecaries' Act was subjected to amendment in the House of Commons, a clause was introduced to give to general practitioners a power to charge, and obtain payment of, a reasonable sum for their time and attendance as medical practitioners. On the second reading of the Bill, the present Lord Brougham, (then Mr. Brougham) who took an active part in the measure, and, I believe, brought it forward, rose, and said, that he should withdraw this clause, as be was given to understand that it would interfere too much with the privileges and usages of the other branches of the profession. Now, at whose suggestion did this withdrawal take place? Thank Heaven! the day is past when that party can exert such a baneful influence in either House of Parliament ; but what is still the interest and inclination of the parties in question? Talk of the medical man being poor, being in debt, being badly paid! Who can wonder at his condition? At work for the public incessantly, with scarcely time to attend to his private concerns, his whole life occupied in medical duties, his youth, his manhood, his old age, night and day, Sunday and reek-day, meal time and bed

\section{AWARD OF THE ROGET MEDAL.}

To the Editor of THE LANCET.

SIR:-I have seen the various notices which have recently appeared in your Journal respecting the award of the Royal and Copley Medals by the Council of the Royal Society. The question at issue is one of considerable interest and importance, and has become one of notoriety, and of much discussion amongst the Fellows of the R.S., and I quite agree with your sensible correspondent "F.R.S." in thinking that " the matter is now in a state which calls imperatively for explanation, as well for the credit of the Committee, as for individual justice."

Dr. Roget is charged with having imposed upon the Committee, and palmed upon them papers as containing discoveries, which, in reality, contain none; and with having rewarded some sinister services rendered to himself by Mr. Newport, by obtaining for Mr. Newport the Roval Medal.

The Committee is charged with having wished, but not dared, to revoke their award of the Royal Medal to Mr. Newport, and with having endeavoured to correct one mistake by the commission of another, in the further award of the Copley Medal to Mr. Kiernan.

Mr. Kiernan is charged with having meanly acquiesced in an arrangement of the Committee to give him the Copley Medal, to quiet his disappointment at having been unjustly deprived of the Royal Medal.

If these charges be true, a flagrant outrage has been committed upon the interests of science, the munificence of Royalty, the reputation of the R.S., and the sacred trusts of office, by an individul, which demands public exposure. But if they he not true, 